\title{
PENGARUH MODEL PEMBELAJARAN INKUIRI TERBIMBING PADA PEMBELAJARAN FISIKA UNTUK MENINGKATKAN HASIL BELAJAR SISWA
}

\author{
Nurfarida, Bahtiar, Nevi Ernita \\ Program Studi Tadris Fisika, FTK Universitas Islam Negeri Mataram \\ Korespondensi: nurfrd12@gmail.com
}

\begin{abstract}
Abstrak: Penelitian ini bertujuan untuk mengetahui pengaruh model pembelajaran inkuiri terbimbing terhadap hasil belajar siswa fisika pada materi momentum dan impuls di SMA Negeri 8 Mataram Tahun Pelajaran 2018/2019. Teknik pengambilan sampel menggunakan Sluster Random Samling. Jenis penelitian yang digunakan adalah quasi eksperimental design dengan desain penelitian pretest-posttest control grup desain. Berdasarkan hasil analisis data dalam penelitian ini dengan menggunakan uji-t diperoleh $t_{\text {tabel }}=2,021$ dan $t_{\text {hitung }}=8,35$, maka diketahui nilai $\mathrm{t}_{\text {hitung }}(8,35)>\mathrm{t}_{\text {tabel }}(2,021)$ dengan $\mathrm{dk}$ yang besarnya $\mathrm{dk}=\mathrm{n} 1+\mathrm{n} 2-2$ dengan

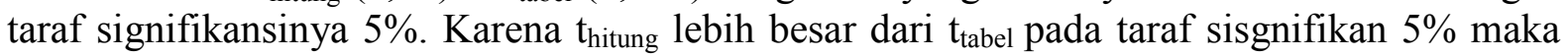
$\mathrm{H}_{0}$ ditolak dan $\mathrm{H}_{\mathrm{a}}$ diterima. Hasil penelitian ini, menunjukkan bahwa secara signifikan terdapat pengaruh model pembelajaran inkuiri terbimbing pada peningkatkan hasil belajar fisika siswa pada materi momentum dan impuls di SMA Negeri 8 Mataram Tahun Pelajaran $2018 / 2019$.
\end{abstract}

Kata Kunci: Model Inkuiri Terbimbing, Hasil Belajar, Pembelajaran Fisika

\section{THE EFFECT OF GUIDED INQUIRY LEARNING MODELS IN PHYSICAL LEARNING TO IMPROVE STUDENT'S LEARNING OUTCOMES}

Abstract: This study aims to determine the effect of guided inquiry learning models on physics student learning outcomes on the material momentum and impulses at SMA Negeri 8 Mataram in academic year of 2018/2019. The sampling technique uses the Random Samling Sluster. This type of research is a quasi experimental design with a pretest-posttest control group design research design. Based on the results of data analysis in this study using the ttest obtained $t_{\text {table }}=2.021$ and $t_{\text {count }}=8.35$, it is known the value of $t_{\text {count }}(8.35)>t_{\text {table }}(2.021)$ with $d k$ the magnitude of $d k=n 1+n 2-2$ with a level the significance is $5 \%$. Because $t_{\text {count }}$ is greater than $t_{\text {table }}$ at a significant level of $5 \%$, HO is rejected and Ha is accepted. The results of this study indicate that there is a significant influence of guided inquiry learning models on improving student physics learning outcomes in the material of momentum and impulses at SMA Negeri 8 Mataram in academic year of 2018/2019.

Keywords: Guided Inquiry Model, Learning Outcomes, Physics Learning

\section{PENDAHULUAN}

Pendidikan adalah pengajaran yang diselenggarakan di sekolah sebagai lembaga tempat mendidik (mengajar). Pendidikan merupakan segala pengaruh yang diupayakan sekolah terhadap anak dan remaja yang diserahkan sekolah agar mempunyai kemampuan kognitif dan kesiapan mental yang sempurna dan berkesadaran maju yang berguna bagi mereka untuk terjun ke masyarakat, menjalin hubungan sosial, dan memikul tanggung jawab mereka sebagai individu maupun sebagai makhluk sosial. Dalam keseluruhan proses 
pendidikan di sekolah, kegiatan belajar merupakan kegiatan yang paling pokok. Ini berarti bahwa berhasil tidaknya pencapaian tujuan pendidikan banyak bergantung kepada bagaimana proses belajar yang dialami oleh siswa sebagai anak didik.

Belajar adalah suatu proses atau serangkaian kegiatan yang terjadi secara terus menerus dan berjenjang, hal ini dimaksudkan untuk mencapai perkembangan yang lebih maju serta perubahan-perubahan pada diri seseorang. Istilah belajar juga diartikan berubah yaitu usaha mengubah tingkah laku. Sehingga akan membawa suatu perubahan pada siswa yang belajar. Perubahan yang terjadi pada siswa yang belajar bisa juga berupa pencapain hasil belajar yang meningkat.

Meningkatnya hasil belajar siswa salah satunya di pengaruhi oleh begaimana cara seorang guru mengajarkan materi pembelajaran di dalam kelas. Namun Pada kenyataannya, pembelajaran di dalam kelas sering ditemui bahwa guru yang lebih aktif dalam proses pembelajaran sehingga menyebabkan siswa cenderung pasif dan lebih banyak menunggu sajian guru dari pada mencari dan menemukan sendiri pengetahuan, keterampilan atau sikap yang mereka butuhkan. Dalam proses pembelajaran guru hanya menggunakan metode ceramah sehingga penyampaian materi cenderung monoton dan tidak mengaktifkan siswa yang menyebabkan rendahnya hasil belajar siswa.

Fisika merupakan salah satu bagian dari sains yang mendasari perkembangan teknologi maju dan konsep hidup harmonis dengan alam. Salah satu fungsi pembelajaran fisika yaitu untuk mengembangkan pengalaman siswa dalam merumuskan masalah, mengajukan dan menguji hipotesis melalui percobaan, merancang dan mengumpulkan, mengolah dan menafsirkan data, serta megkomunikasikan hasil percobaan secara lisan dan tertulis. Pembelajaran fisika adalah pelajaran yang sangat penting, meskipun pembelajaran fisika sangat penting, namun pada kenyataan pembelajaran fisika adalah momok yang ditakuti oleh siswa, karena dalam porses pembelajaran siswa kurang terlibat secara langsung dengan kegiatan belajar mengajar. Hal ini menyebabkan siswa kurang dalam pemahaman konsep fisika dan hasil belajar siswa menjadi rendah.

Berdasarkan hasil observasi dan wawancara dengan salah seorang guru fisika yaitu Ibu Sri Yulianti di SMA Negeri 8 Mataram, bahwa pembelajaran fisika yang berlangsung masih didominasi oleh guru serta kurang bervariasi. Proses pembelajaran lebih sering menggunakan metode ceramah. Pembelajaran yang berlangsung masih konvensional dengan latihan soal dan penghafalan rumus-rumus saja tanpa mengkaitkan dengan praktik dalam kehidupan sehari-hari, sehingga menyebabkan siswa hanya berpatokan pada teori-teori tanpa ada penerapanya sehingga kurangnya kesempatan siswa untuk memiliki pengalaman belajar yang nyata dan aktif. Hal ini mengakibatkan aktivitas belajar dan hasil belajar fisika siswa kurang maksimal. Alat ukur yang digunakan untuk mengetahui pemahaman konsep fisika peserta didik dilakukan dengan cara mengevaluasi setiap akhir materi dalam bentuk test uraian. Hal ini ditunjukan oleh data hasil wawancara yang diperoleh dari gurunya rata-rata tidak memenuhi standar kelulusan yang di tetapkan. Dimana KKM yang telah ditetapkan di sekolah 75 sedangkan hasil yang diperoleh peserta didik tidak mencapai KKM.

Keberhasilan proses belajar siswa di sekolah dapat diamati salah satunya dari hasil belajar yang dicapai. Menurut Alfiani (dalam Qurroti 2016), pencapaian hasil belajar yang tinggi tersebut dipengaruhi oleh faktor internal dan eksternal. Guru merupakan faktor eksternal yang berperan penting dalam penunjang keberhasilan belajar siswa. Kebehasilan tersebut tidak lepas dari kemapuan guru memilih pendekatan, model, metode, strategi pembelajaran yang dapat membuat siswa lebih aktif dalam proses belajar di dalam kelas supaya hasil belajar yang merupakan produk dari suatu proses pembelajaran dapat lebih baik. 
Salah satu model yang dapat melibatkan siswa secara aktif dalam pembelajaran dan sesuai dengan hakikat fisika yang terdiri atas proses dan produk adalah model inkuiri terbimbing.

Model inkuiri terbimbing adalah model mengajar yang memungkinkan siswa untuk bergerak selangkah demi selangkah dari mengidentifikasi masalah, mendefinisikan hipotesis, merumusan masalah, mengumpulan data, memverifikasi hasil, dan generalisasi kesimpulan (Massialas dalam Qurroti (2016)), Model inkuiri termbimbing sangat memungkinkan siswa terlibat secara aktif. Karena siswa melakukan sebagian besar pekerjaan yang harus dilakukan. Mereka menggunakan kemampuan berpikirnya untuk mempelajari gagasan, memecahkan berbagai masalah, dan menerapkan apa yang mereka pelajari. Pembelajaran dengan menerapkan model inkuiri terbimbing memberikan kebebasan kepada siswa untuk mengembangkan konsep yang mereka pelajari dan mereka diberi kesempatan untuk memecahkan masalah yang mereka hadapi secara berkelompok. Jadi dapat ditarik kesimpulkan bahwa model pembelajaran inkuiri terbimbing adalah model yang bertujuan untuk melibatkan siswa secara aktif dalam kegiatan belajar menggajar (KBM), dimana dalam pelaksanaannya guru menyediakan bimbingan yang cukup luas untuk siswa.

Beberapa penelitian yang telah dilakukan sebelumnya mengenai pengaruh model inkuiri terbimbing yaitu peneliti pertama oleh A'yunin Qurroti, dkk. (2016), yang menunjukan bahwa model inkuiri terbimbing berpengaruh signifikan terhadap aktivitas belajar dan hasil belajar siswa. Penelitian yang kedua mengenai model inkuiri terbimbing dilakukan oleh Sugiarti (2018), yang menunjukan bahwa model inkuiri terbimbing berpengaruh terhadap peningkatan kemampuan psikomotorik siswa. Penelitian yang ketiga mengenai model inkuiri terbimbing dilakukan oleh Fahrudin, dkk. (2014), yang menunjukan bahwa model inkuiri terbimbing berpengaruh positif dan peningkatan yang signifikan terhadap keterampilan proses sains siswa. Penelitian yang keempat mengenai model inkuiri terbimbing dilakukan oleh Agustin, dkk. (2014), yang menunjukan bahwa model inkuiri terbimbing dapat meningkatkan keterampilan berpikir kritis siswa dengan presentase hasil yang lebih tinggi. Penelitian yang kelima mengenai model inkuiri terbimbing dilakukan oleh Ernita N, dkk, yang menunjukan bahwa model pembelajaran inkuiri terbimbing dapat meningkatkan hasil belajar kognitif dan psikomotorik fisika siswa.

Berdasarkan uraian latar belakang di atas peneliti tertarik untuk melakukan penlitian dengan judul "Pengaruh Model Pembelajaran Inkuiri Terbimbing pada Pembelajaran Fisika untuk Meningkatkan Hasil Belajar Siswa Pada Materi Momentum dan Impuls Kelas X MIA Di SMA Negeri 8 Mataram".

\section{METODE}

Penelitian ini merupakan jenis penelitian quasi experimental design dengan menggunakan dua kelompok kelas, yaitu kelompok kelas eksperimen dan kelas kontrol. Pada kelompok kelas eksperimen, diberikan pembelajaran dengan menggunakan model pembelajaran inkuiri terbimbing sedangkan kolompok kelas kontrol dengan menggunkan model konvesional. Penelitian ini mengukur peningkatan hasil belajar siswa pada kedua kelompok kelas tersebut. desain penelitian pretest-postest control grup desain. Desain penelitian ini dapat dilihat pada Tabel 1 .

\begin{tabular}{cccc}
\multicolumn{4}{c}{ Tabel 1 Desain penelitian } \\
\hline Kelompok & $\begin{array}{c}\text { Pre- } \\
\text { test }\end{array}$ & Treatment & Post-test \\
\hline Eksperimen & $\mathrm{Y}_{1}$ & $\mathrm{X}_{1}$ & $\mathrm{Y}_{2}$
\end{tabular}




\begin{tabular}{llll} 
kontrol & $\mathrm{Y}_{1}$ & $\mathrm{X}_{2}$ & $\mathrm{Y}_{2}$ \\
\hline
\end{tabular}

Keterangan:

$\mathrm{X}_{1} \quad=$ Model Pembelajaran Inkuiri Terbimbing

$\mathrm{X}_{2} \quad=$ Model konvesional

$\mathrm{Y}_{1} \quad=$ Tes Awal (Pre-Test)

$\mathrm{Y}_{2} \quad=$ Tes Akhir (Post-Test)

Populasi dalam penelitian ini adalah seluruh siswa kelas X SMA Negeri 8 Mataram semester kedua tahun ajaran 2018/2019. Berdasarkan karakteristik populasi maka dalam pengambilan sampel dilakukan dengan menggunakan teknik cluster random sampilng yaitu dengan cara pemilihan kelas dilakukan tanpa memperhatikan adanya pembagian kelas unggulan karena kelas X MIA terdiri dari 5 kelas yang rata-rata kemampuan belajarnya sama. Berdasarkan ketentuan pemilihan sampel, maka dipilih dua 2 kelas, yaitu siswa kelas X MIA 2 sebagai kelas eksperimen dan siswa kelas X MIA 3 sebagai kelas kontrol. Instrumen yang digunakan dalam penelitian ini yaitu dengan cara memberikan tes soal yang berkaitan dengan materi momentum dan impuls. Tes ini dibuat dalam bentuk pilihan ganda dan essay sebanyak 25 butir soal.

Analisis data yang digunakan yaitu pengujian normalitas data yang diperoleh dari hasil penelitian berdistribusi normal atau tidak, data yang dimaksud adalah skor hasil tes soal yang diperoleh dari siswa. Uji homogenitas digunakan untuk mengetahui apakah vairans antara pretest dan posttest sama atau berbeda. Pengujian hipotesis digunakan untuk melihat apakah hipotesis yang telah dirumuskan didukung oleh data yang telah diperoleh, sehingga hipotesis tersebut harus harus diuji.

\section{HASIL DAN PEMBAHASAN}

Hasil

Berdasarkan hasil penelitian yang telah dilakukan, maka dapat dilihat hasil belajar siswa yang telah diperoleh dalam pelaksanaan penelitian melalui pretest dan posttest dengan instrumen berupa soal pilihan ganda dan essay. Data hasil belajar siswa dapat dilihat pada tabel 1 dan tabel 2 berikut:

Tabel 1 Data Hasil Pre-Test

\begin{tabular}{ccccccc}
\hline & Sampel & $\begin{array}{c}\text { Jumlah } \\
\text { Siswa }\end{array}$ & $\begin{array}{c}\text { Nilai } \\
\text { Max }\end{array}$ & $\begin{array}{c}\text { Nilai } \\
\text { Min }\end{array}$ & $(\bar{X})$ & $\begin{array}{c}\text { Standar } \\
\text { Deviasi }\end{array}$ \\
\hline 1 & $\begin{array}{l}\text { Kelas } \\
\text { eksperimen }\end{array}$ & 21 & 81 & 58 & 72,48 & 7,18 \\
& Kelas kontrol & 21 & 67 & 29 & 49,76 & 10,22 \\
\hline
\end{tabular}

Pada tabel di atas dapat dilihat bahwa nilai Pre-Test pada kelas eksperimen dengan banyak responden 21 siswa memperoleh nilai tertinggi sebesar 48 dan nilai terendah sebesar 14, sehingga mendapatkan nilai rata-rata sebesar 29,90. Sedangkan nilai Pre-Test pada kelas 
kontrol dengan banyak responden 21 siswa memperoleh nilai tertinggi sebesar 43 dan nilai terendah sebesar 15, sehingga mendapatkan nilai rata-rata sebesar 27,86.

Tabel 2 Data Hasil Post-Test

\begin{tabular}{clccccc}
\hline No & Sampel & $\begin{array}{c}\text { Jumlah } \\
\text { Siswa }\end{array}$ & $\begin{array}{c}\text { Nilai } \\
\text { Max }\end{array}$ & $\begin{array}{c}\text { Nilai } \\
\text { Min }\end{array}$ & $(\bar{X})$ & $\begin{array}{c}\text { Standar } \\
\text { Deviasi }\end{array}$ \\
\hline 1 & $\begin{array}{l}\text { Kelas } \\
\text { Eksperimen }\end{array}$ & 21 & 48 & 14 & 29,90 & 8,86 \\
2 & Kelas Kontrol & 21 & 43 & 15 & 27,86 & 8,24 \\
\hline
\end{tabular}

Pada tabel di atas dapat dilihat bahwa nilai Post-Test pada kelas eksperimen dengan banyak responden 21 siswa memperoleh nilai tertinggi sebesar 81 dan nilai terendah sebesar 58, sehingga mendapatkan nilai rata-rata sebesar 72,48. Sedangkan nilai Pre-Test pada kelas kontrol dengan banyak responden 21 siswa memperoleh nilai tertinggi sebesar 67 dan nilai terendah sebesar 29, sehingga mendapatkan nilai rata-rata sebesar 49,76.

Berdasarkan tabel di atas, secara umum dapat dilihat bahwa hasil belajar siswa dari tes awal dan tes akhir yang diberikan diperoleh nilai rata-rata kelas eksperimen lebih tinggi dibandingkan nilai rata-rata kelas kontrol. Untuk memperjelas gambaran perbandingannya dapat dilihat pada diagram batang berikut ini:

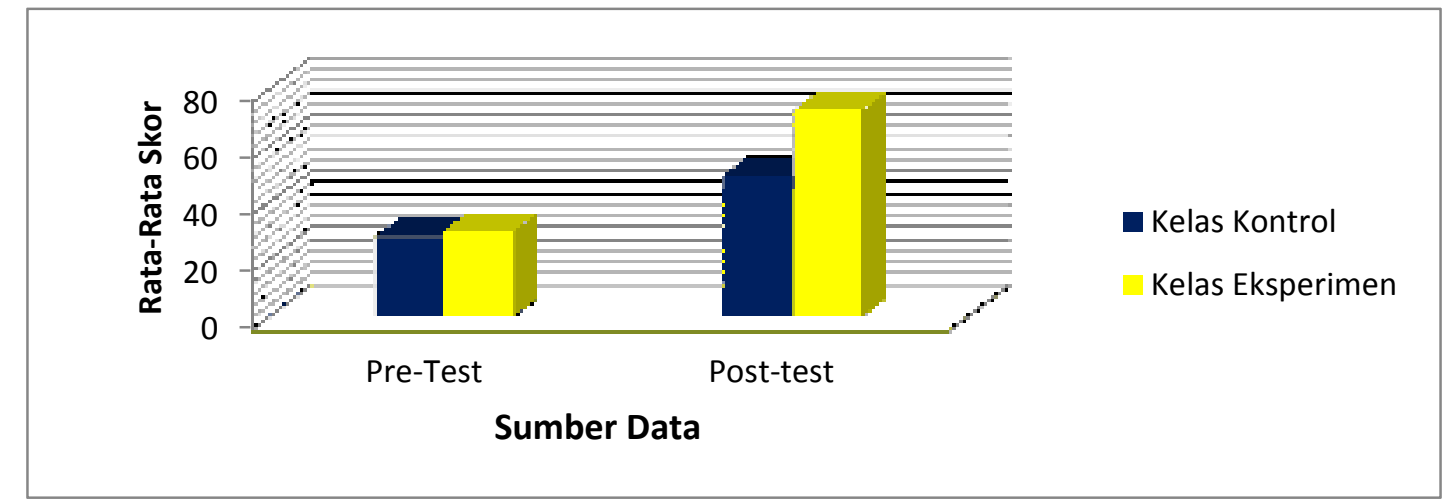

\section{Gambar 1 Diagram Perbandingan Rata-Rata Nilai Pre-Test dan Post-Test Hasil Belajar Siswa Kelas Kontrol dan Kelas Eksperimen}

Berdasarkan hasil gambar diagram batang di atas, dapat disimpulkan bahwa data hasil belajar siswa dari tes awal dan tes akhir yang diberikan diperoleh nilai rata-rata kelas eksperimen lebih tinggi dibandingkan nilai rata-rata kelas kontrol. Hal ini menunjukan bahwa penggunaan model pembelajaran inkuiri terbimbing berpengaruh dalam meningkatkan hasil belajar fisika siswa. Hasil perbandingan nilai rata-rata kelas eksperimen dan kelas kontrol.

\section{Pembahasan}

Pendidikan adalah suatu pengajaran yang diselenggarakan di sekolah sebagai lembaga tempat mendidik (mengajar). Seperti yang telah kita ketahui bahwa dalam keseluruhan proses pendidikan di sekolah, kegiatan belajar merupakan kegiatan yang paling pokok. Hal ini ditunjukan bahwa berhasil tidaknya pencapaian tujuan pendidikan banyak bergantung kepada 
bagaimana proses belajar yang dialami oleh siswa sebagai anak didik. Dalam keberhasilan proses belajar siswa di sekolah diamati salah satunya dari hasil belajar yang dicapai. Menurut Afiani (dalam Qurroti 2016), pencapai suatu hasil belajar yang tinggi dapat dipengaruhi oleh faktor internal dan faktor eksternal. Guru adalah faktor eksternal yang memiliki peranan penting dalam penunjang keberhasilan belajar siswa. Keberhasilan tersebut tidak terlepas dari kemampuan seorang guru dalam memilih pendekatan, model, metode, strategi pembelajaran yang dapat membuat siswa lebih akfit dalam proses kegiatan pembelajaran di dalam kelas supaya hasil belajar yang merupakan produk dari suatu proses pembelajaran dapat lebih baik lagi. Selain dalam pemilihan model atau metode pembelajaran seorang guru harus pandai dalam memposisikan penggunaan model atau metode pembelajaran agar waktu yang digunakan dalam pembelajaran bisa lebih efisien sehingga membuat siswa senang dalam belajar.

Dalam penelitan ini model pembelajaran yang diterapkan yaitu model inkuiri terbimbing. Model inkuiri terbimbing adalah model pembelajaran yang bertujuan untuk melibatakan siswa secara aktif dalam melaksakana kegiatan belajar mengajar, dimana dalam pelaksanaannya guru menyediakan bimbingan yang cukup luas untuk siswa. Dengan menerapkan model pembelajaran inkuiri terbimbing ini siswa diberikan kebebasan untuk mengembangkan konsep yang mereka pelajari dan siswa diberi kesempatan untuk memecahkan masalah yang mereka hadapi secara berkelompok dan memberikan semacam penutup ketika siswa telah mampu memecahkan masalah yang diberikan oleh guru.

Dalam proses kegiatan belajar mengajar siswa merupakan subjek pembelajaran dan bukan objek pembelajaran, oleh karena itu siswa yang lebih banyak berperan aktif dalam pembelajaran dari pada guru, guru hanya sebagai fasilitator yang membimbing siswa dalam proses pemebelajaran sehingga siswa dapat meningkatkan hasil belajar. Berdasarkan uraian diatas bahwa model pembelajaran inkuiri terbimbing adalah model yang memibatkan siswanya secara aktif dalam proses pembelajaran sehingga siswa dapat meningkatkan kemampuan hasil belajaranya tampa harus selalu bergantung pada guru dalam mendapatkan suatu pengetahuan. Hal ini sesuai dengan tujuan yang peneliti angkat yaitu tentang Adanya Pengaruh Model Pembelajaran Inkuiri Terbimbing Terhadap Hasil Belajar Fisika Siswa Pada Materi Momentum dan Impuls Kelas X SMA Negeri 8 Mataram.

Untuk mengetahui pemahaman siswa terhadap materi momentum dan impuls, maka peneliti mengadakan tes, tes ini diadakan dalam dua tahap yaitu pre-test dan post-tes. Pre-test adalah tes yang diberikan sebelum dilaksanakan proses belajar mengajar. Tes ini bertujuan untuk mengetahui sejauh mana siswa dapat menguasai materi yang akan diajarkan. Pest-test adalah tes yang diberikan setelah dilaksanakan proses pembelajaran. Tes ini bertujuan untuk mengetahui sejauh mana tingkatan kemajuan penguasaan materi oleh siswa.

Berdasarkan hasil analisis data yang diperoleh dari pre-test, kedua kelas memiliki nilai rata-rata yang tidak jauh berbeda. Dimana kelas kontrol memiliki nilai rata-rata sebesar 27,86, dengan nilai tertinggi 43 dan nilai terendah 14. Sedangkan pada kelas eksperimen memiliki nilai rata-rata 29,90, dengan nilai tertinggi 48 dan nilai terendah 15 . Berdasarkan hasil nilai dari pre-test dapat menunjukan bahwa kedua kelas memiliki kemampuan awal yang sama sebelum diberikan perlakuan. Peningkatan terjadi setelah diterapkan perlakuan, pada post-test nilai rata-rata kelas kontrol sebesar 49,76, dengan perolehan nilai tertinggi sebesar 67 dan perolehan nilai terendah sebesar 29, sedangkan pada kelas eksperimen nilai rata-rata post-test sebesar 72,48, dengan perolehan nilai tertinggi sebesar 81 dan perolehan nilai terendah sebesar 58 .

Berdasarkan hasil pengujian hipotesis dengan menggunakan uji-t, maka diperoleh $t_{\text {hitung }}(8,35)>t_{\text {tabel }}(2,021)$, maka dapat diambil keputusan bahawa $\mathrm{H}_{\mathrm{a}}$ diterima pada taraf 
signifikan $\alpha=5 \%$. Sehingga dapat disimpulkan bahwa " pengaruh model pembelajaran inkuiri terbimbing efektif terhadap peningkatan hasil belajar siswa yang lebih tinggi dengan penerapan model pembelajaran inkuiri terbimbing yang diajarkan dibandingkan dengan pembelajaran yang tidak diterapkan model pembelajaran inkuiri terbimbing pada materi momentum dan impuls di SMA Negeri 8 Mataram.

Hasil ini juga relevan dengan penelitian terdahulu yang telah dilakukan oleh Ernita N, dengan judul "Penerapan Model Pembelajaran Inkuiri Terbimbing Berbasis Laboratorium dan Pengaruhnya Terhadap Hasil Belajar Fisika Peserta Didik SMA Negeri 8 Mataram". Diperoleh bahwa model pembelajaran inkuiri terbimbing berbasis laboratorium berpengaruh terhadap peningkatan hasil belajar fisika siswa.

Keaktifan siswa dalam kegiatan pembelajaran pada materi momentum dan impuls adalah suatu hal sangat penting dalam meningkatkan hasil belajar siswa, karena materi momentum dan impuls adalah salah satu materi fisika yang dalam penerapanya banyak sekali dialam dalam kehidupan sehari-hari sehingga siswa membutuhkan pemahaman dan menerapkan konsepnya dalam mengkaitakan ke dalam kehidupan, oleh karena itu siswa harus lebih aktif dalam proses pemebelajaranya. Aktif tidaknya siswa dapat dilihat dari bagaimana cara siswa aktif dalam suatu kegiatan kelompok maupun individu dalam menemukan sendiri jawaban dari permasalahan yang diberikan oleh guru.

Untuk meningkatkan keaktifan dan hasil belajar siswa diperlukan model pembelajaran yang tepat. Salah satu model pembelajaran yang menigkatkan keaktifan dan hasil belajar adalah model inkuiri terbimbing. Penggunaan model pembelajaran inkuiri terbimbing pada materi Momentum dan Impuls secara signifkan memberikan pengaruh yang berbeda pada kelas ekperimen sehingga membuat siswa lebih aktif dalam menemukan konsep-konsep pembelajaran dan meningkatkan hasil belajar fisika. Hal ini diperkuat oleh penelitan yang telah dilakukan sebelumnya oleh Wahyuni Roni, dkk. (2016) yang menunjukan bahwa nilai rata-rata tes hasil belajar fisika yang menggunakan model pembelajaran inkuiri terbimbing dengan metode eksperimen lebih tinggi dibandingkan dengan yang menggunakan model pembelajaran konvesional. Penelitan lain juga yang telah dilakukan oleh Kurniawati Desi, dkk. (2016) yang menunjukan bahwa penerapan model pembelajaran inkuiri terbimbing dilengkapi LKS dapat meningkatkan keterampilan proses sains dan prestasi belajar siswa, hal dikarenakan dalam model pembelajaran inkuiri menekankan suatu proses pembelajaran dengan tahapan ilmiah, sehingga proses pembelajaran di dalam kelas lebih aktif sehingga pemahaman konsep dan prestasi hasil belajar siswa meningkat. Berdasarkan penelitan yang telah dilakukan bahwa model pembelajaran inkuiri terbimbing dapat meningkatkan hasil belajar siswa pada materi momentum dan impuls.

Dalam pelaksanaan kegiatan belajar mengajar pada kelas eksperimen, siswa antusias dalam mengikuti setiap kegiatan belajar mengajar, guru mampu menciptakan suasana belajar yang menyenangkan bagi siswa dan guru sebagai vasilitator, dimana dalam pembelajaran lebih dominan oleh siswa yang secara aktif dalam proses pembelajaran yang berlangsung di kelas. Guru menggunakan model inkuiri terbimbing yakni model pembelajaran yang dimulai dari pengidentifikasi masalah, mengidentifikasi hipotesis, merumuskan masalah, mengumpulkan data, memverifikasi hasil dan akhiri dengan membuat kesimpulan yang dimana dalam penyelsesain siswa diorganisasikan kedalam kelompok kecil.

Dalam kelompok siswa menentukan tiap penyelasiain dari permasalahan yang berikan oleh guru dengan melaksanakan kegiatan praktikum. Pada tahap ini kemampuan siswa dalam menyelesaikan permasalahan berdasarkan dari hasil praktikum dan perolehan konsep yang cari sendri oleh siswa terkait materi momentum dan impuls. Setelah memyelesaikan permasalah dan memperoleh data para siswa dituntut untuk menarik kesimpulan berdasarkan 
praktikum dan memperesentasikan hasil praktikum di depan kelas dengan mengirimkan perwakilan satu orang dari tiap kelompok. Sehingga dalam proses belajar siswa tampak lebih aktif dalam melaksanakan tiap tahap prosedur praktikum, keaktifan dan hasil siswa dapat juga dilihat dari beberapa jawaban yang berbeda-beda dari tiap kelompok. Hal ini menunjukan bahwa siswa menggunakan kemampuan berpikirnya untuk mempelajari gagasan, memecahkan berbagai masalah, dan menerapkan apa yang mereka pelajari sehingga siswa dapat meningkatkan hasil belajarnya. Sedangkan pada kelas kontrol antusias siswa dalam proses belajar mengajar kurang aktif hal ini disebebakan karena siswa tidak mencari pengetahuannya sendiri dan siswa cenderung menunggu pengetauan yang di sampaikan oleh guru. Jadi keaktifan siswa dalam mengikuti kegiatan belajar mengajar tergantung dari model, metode, dan strategi yang di gunakan oleh guru.

Berdasarkan penjelasan diatas dapat disimpulkan bahwa model pembelajaran inkuiri terbimbing cocok untuk dugunakan di jenjang pendidikan sekolah menengah atas (SMA) karena pada jenjang pendidikan SMA pola pikir anaknya lebih luas, kristis, dan rasa ingin tahu akan sesuatu lebih besar.

Penerapan model pembelajaran inkuiri terbimbing lebih mengaktifkan siswa karena inkuiri terbimbing memiliki kelebihan yaitu antara lain: yang pertaman menekankan pada perkembangan aspek kognitif, apek afektif, dan aspek psikomotorik. Sehingga dalam pemebelajarannya siswa dapat mememperoleh ketiga aspek dalam pembelajaran secara seimbang tanpa meninti beratkan pada satu aspek perkembangan sehingga proses pembelelajaran dengan inkuiri dapat lebih bermakna. Hal ini diperkuat oleh penelitian yang telah dilakukan oleh Sugiarti (2018) yang menunjukan bahwa rata-rata kemampuan psikomotorik siswa yang menggunakan model pemebelajaran inkuiri terbimbing diperoleh dengan kategori baik. Karena dalam model pembelajaran inkuiri terbimbing siswa secara aktif melakukan semua langkah-langkah dalam proses penyelidikan sesuai dengan tahapan pembelajaran inkuiri. Sehingga pada setiap pertemuan kemampuan psikomotorik siswa terus mengalami peningkatan. Penelitiam lain juga yang dilakukan oleh Nasution, dkk. (2016) yang menunjukan bahwa adanya perbedaan dan interaksi terhadap penggunaan model pembelajaran inkuiri terbimbing pada kreatifitas dan hasil belajar kognitif tinggi dengan melalui penerapan model pembelajaran inkuiri terbimbing siswa lebih aktif dan termotivasi untuk melalukan suatu kegiatan eksperimental, sehingga aspek kognitif tinggi siswa lebih meningkat dan menhasilkan nilai yang bagus. Kelebihan yang kedua yaitu memberikan kesempatan kepada siswa untuk belajar sesuai dengan gaya belajar mereka. Pada kelebihan kedua ini siswa diberikan kebebasan dalam menentukan gaya belajarnya dimana pada saat proses belajar siswa dapat mencari atau memperoleh sendiri pengetahuan sesui dengan cara yang mudah siswa pahami dalam proses belajarnya. Hal ini terbukti dari penelitian sebelumnya yang dilakukan oleh Nugroho Sugeng (2012) yang menunjukan bahwa pembelajaran inkuiri terbimbing melalui laboraorium virtuil dan laboratorium riil memilik pengaruh secara signifikan terhadap gaya belajar siswa yang dapat dilihat dari adanya pengaruh terhadap prsetasi kognitif dan tidak berpengaruh terhadap prestasi efektif belajar siswa. Ketiga yaitu adanya perubahan tingkah laku siswa berkat adanya suatu pengalaman. Maksudnya berdasarkan pengalam disini yaitu dimana siswa akan mengalami perubahan pada setiap tingkah lakunya dalam mengkaitan setiap materi dengan pengalamannya sendiri karena dalam inkuiri terbimbing tiap tahap dalam proses pembelajarannya melatih siswa untuk bisa menjadi seorang memiliki sikap bertanggung jawab terhadap sesuatu yang diperolehnya. Hal ini juga terbukti dari penelitian sebelumnya yang telah dilakukan oleh Fairuzabadi Afrizal, dkk. (2017) yang menunjukan bahwa penerapan model pembelajaran inkuiri terbimbing dengan video berbasis kontekstual dalam pembelajaran IPA dapat 
membuat siswa lebih aktif dan termotivasi dalam pembelajaran sehingga hasil belajar yang diperoleh siswa lebih baik, karena siswa merasa tertarik dalam kegiatan pembelajaran dengan melakukan penyelidikan secara ilmiah untuk menemukan konsep dengan disertai media video berbasis kontekstual dalam model inkuiri terbimbing, siswa dapat mengkaitkan materi dengan pengalam siswa di kehidupan sehari-hari. Keempat yaitu tidak menghambat siswa yang memiliki kemampuan di atas rata-rata. Maksudnya siswa yang memiliki kemapuan belajar di atas rata-rata tidak terhambat oleh siswa yang memiliki kemapuan lemah dalam belajar karena setiap tahap dalam inkuri terbimbing akan melibatkan setiap siswanya aktif dalam kegiatan belajar. Hal ini sejalan dengan penelitian sebelumnya yang dilakukan oleh Nurcahyati Kartika, dkk. (2018) yang menunjukan bahwa terdapat pengaruh yang signifikan terhadap hasil belajar siswa dan dapat meningkatkan kemampuan berpikir siswa dikarenakan penggunaan LKS yang berbasi inkuiri terbimbing. Pengaruh yang ditimbulkan dari LKS yang berbasis model pembelajaran inkuiri terbimbing terhadap hasil belajar dapat terjadi karena kegiatan pembelajaran yang menggunakan LKS membuat 11siswa menjadi lebih aktif, sehingga siswa dapat menemukan dan memahami konsep-konsep dasar materi pembelajaran yang berlangsung.

Berdasarkan uraian diatas dapat disimpulkan bahwa model pembelajaran inkuiri terbimbing sesuai untuk diterapkan dalam proses pembelajaran karena model inkuiri terbimbing adalah model yang melibatkan kemampuan siswa secara maksimal untuk mencari dan menyelidiki secara sistematik, kritis, logis, dan analisis sehingga siswa dapar merumuskan sendiri penemuannya dengan percaya diri.

\section{PENUTUP}

Berdasarkan hasil penelitian dan pembahasan, dapat disimpulkan bahwa terdapat pengaruh hasil belajar siswa pada pembelajaran Fisika menggunakan model pembelajaran inkuiri terbimbing. Hasil tersebut di dapatkan dari perhitungan uji-t, hasil tersebut diperoleh dari interpretasi nilai $\mathrm{t}_{\text {hitung }}=8,35$ dan $\mathrm{t}_{\text {tabel }}=2,021$, maka diperoleh nilai $\mathrm{t}_{\text {hitung }}(8,35)>\mathrm{t}_{\text {tabel }}$ $(2,021)$ dengan $\mathrm{dk}=\mathrm{n} 1+\mathrm{n} 2-2$ dan taraf signifikan sebesar $(\alpha)$ sebesar $5 \%$. Karena $t_{\text {hitung }}$ lebih besar dari $t_{\text {tabel}}$, maka diperoleh bahwa Ha diterima dan Ho ditolak. Pada hasil penelitian menunjukan bahwa model pembelajaran yang tepat untuk meningkatkan hasil belajar Fisika siswa adalah model inkuiri terbimbing. Hal tersebut dapat dilihat dari rata-rata skor post-test dan pre-test. Pada kelas yang diterapkan model inkuiri terbimbing memiliki rata-rata skor post-test sebesar 72,48, sedangkan rata-rata skor pre-test sebesar 29,90.

\section{UCAPAN TERIMAKASIH}

Pada kesempatan ini peneliti ingin mengucapkan terimakasih banyak kepada semua pihak yang telah membantu pelaksanaan penelitian ini. Ucapan terimakasih dan penghargaan peneliti sampaikan kepada pihak Program Studi Tadris Fisika, Fakultas Tarbiyah dan Keguruan Universitas Islam Negeri Mataram. Selain itu, penghargaan dan ucapan terimakasih juga peneliti sampaikan kepada dosen pendidikan fisika yang telah terlibat dalam penelitian ini, kedua orang tua dan teman-teman yang telah memberikan doa dan semangat kepada peneliti dalam menyelesaikan penelitian ini.

\section{DAFTAR PUSTAKA}

A'yunin, Q., Indrawati, \& Subiki. (2016). Penerpan Model Inkuiri Terbimbing (Guided Inquiry) pada Pemebalajaran Fisika Materi Listrik Dinamis Di SMK. Jurnal Pembelajaran Fisika, 5(2),150. 
Bahtiar. (2015). Strategi Belajar Mengajar Sains (IPA). Mataram: CV Sanabil.

Ernita, N., Harjono, A., \& Sridana, N. Penerapan Model Pembelajaran Inkuiri Terbimbing Berbasis Laboratorium dan Pengaruhnya terhadap Hasil Belajar Fisika Peserta Didik SMA Negeri 8 Mataram. Jurnal Ilmiah Pendidikan Fisika "Lensa”, 1(2), 104-107.

Fairuzabadi, A., Prihandono, T., \& Purta, P. D. A. (2017). Penerapan Model Pembelajarran Inkuiru Terbimbing dengan Video Berbasis Kontekstual dalam Pembelajaran IPA pada Materi Suhu dan Pengukurannya di SMP. Jurnal Pembelajaran Fisika, 6(1), 107.

Indra, D. N. L., Darmadi, I. W., \& Ali, M. (2016). Penerapan Model Pembelajaran Inkuiri Terbimbing untuk Meningkatkan Keterampilan Akuisisi pada Siswa Kelas X SMA Negeri 5 Palu. Jurnal Pendidikan Fisika Tadulako (JPFT), 4(2), 1.

Kurniawati, D., Masykuri, M., \& Saputro, S. (2016 ). Penerapan Model Pembelajaran Inkuiri Terbimbing Dilengkapi LKS untuk Meningkatkan Keterampilan Proses Sains dan Prestasi Belajar pada Materi Pokok Hukum Dasar Kima Siswa Kelas X MIA 4 SMAN 1 Karanganyar Tahun Pelajaran 2014/2015. Jurnal Pendidikan Kima (JIPK), 5(1), 94.

Nasution, R., Bukit, N., \& Ginting, E. M. (2016). Pengaruh Model Pembelajaran Inkuiri Terbimbing dan Kreativitas Terhadap Kognitif Tinggi. Jurnal Pendidikan Fisika, 5(2), 5-102.

Nugroho, S., Suparmi, \& Sarwanto. (2012). Pembelajaran IPA dengan Metode Inkuiri Terbimbing Menggunakan Laboratorium Riil dan Virtual Ditinjau Dari Kemampuan Memori dan Gaya Belajar Siswa. Jurnal Inkuiri, 1(3), 243.

Nurcahyati, K., Distrik, I. W., \& Wahyudi, I. (2018). Pengaruh LKS Berbasis Inkuiri Terbimbing Materi Elastisitas dan Hukum Hooke Terhadap Hasil Belajar Siswa. Journal Of Physics and Science Learnig, 02(2), 7.

Puspaningtyas, K., \& Suparno. (2017). Pengaruh Penerapan Model Inkuiri Terbimbing terhadap Kemampuan Analilis dan Keterampilan Proses Sains. Indonesia Journal of Science and Education, 1(1), 10.

Sadirman. (2005). Interaksi dan Motivasi Belajar Mengajar. Jakarta: Grafindo.

Slameto. (2013). Belajar \& Faktor-Faktor Yang Mempengaruhi. Jakarta: Rineka Cipta.

Sugiarti. (2018). Penilaian Psikomotorik Siswa pada Pembelajaran Fisika Melalui Model Pembelajaran Guided Inkuiry. Journal of Physics and Science Learning, 02(1), 7983. 
Sumarni S., Santoso, B. B., \& Suparman, A. R. (2017). Pengaruh Model Pembelajaran Inkuiri Terbimbing terhadap Hasil Belajar Kognitif Peserta Didik di SMA Negeri 01 Manokwari. Jurnal Nalar Pendidikan, 5(1), 27.

Soyomukti Nurani. (2015). Teori-Teori Pendidikan (Dari Tradisional, (Neo) Liberal, MarxisSosial, Hingga Postmodern. Yogyakarta: Ar-Ruzz Media.

Wahyuni, R., Hikmawati, \& Taufik, M. (2016). Pengaruh Model Pembelajaran Inkuiri Terbimbing dengan Eksperimen terhadap Hasil Belajar Fisika Siswa Kelas XI IPA SMAN 2 Mataram Tahun Pelajaran 2016/2017. Jurnal Pendidikan Fisika dan Teknologi, II(4), 164-168. 